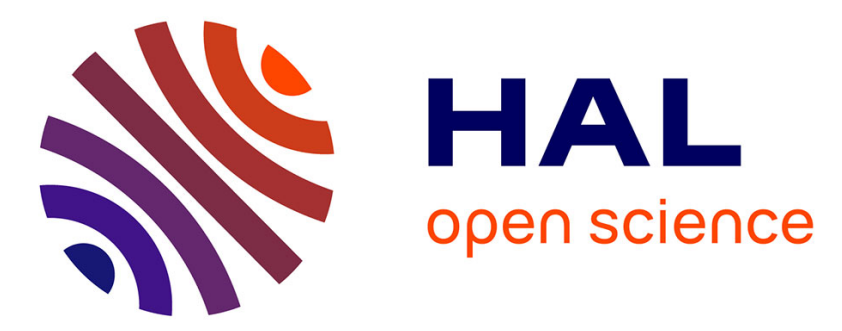

\title{
MONETARY POLICY RULES IN THEORY AND IN PRACTICE: EVIDENCE FROM THE UK AND THE US \\ Juan Paez-Farrell
}

\section{- To cite this version:}

Juan Paez-Farrell. MONETARY POLICY RULES IN THEORY AND IN PRACTICE: EVIDENCE FROM THE UK AND THE US. Applied Economics, 2009, 41 (16), pp.2037-2046. $10.1080 / 00036840701689496$. hal-00582241

\section{HAL Id: hal-00582241 \\ https://hal.science/hal-00582241}

Submitted on 1 Apr 2011

HAL is a multi-disciplinary open access archive for the deposit and dissemination of scientific research documents, whether they are published or not. The documents may come from teaching and research institutions in France or abroad, or from public or private research centers.
L'archive ouverte pluridisciplinaire HAL, est destinée au dépôt et à la diffusion de documents scientifiques de niveau recherche, publiés ou non, émanant des établissements d'enseignement et de recherche français ou étrangers, des laboratoires publics ou privés. 


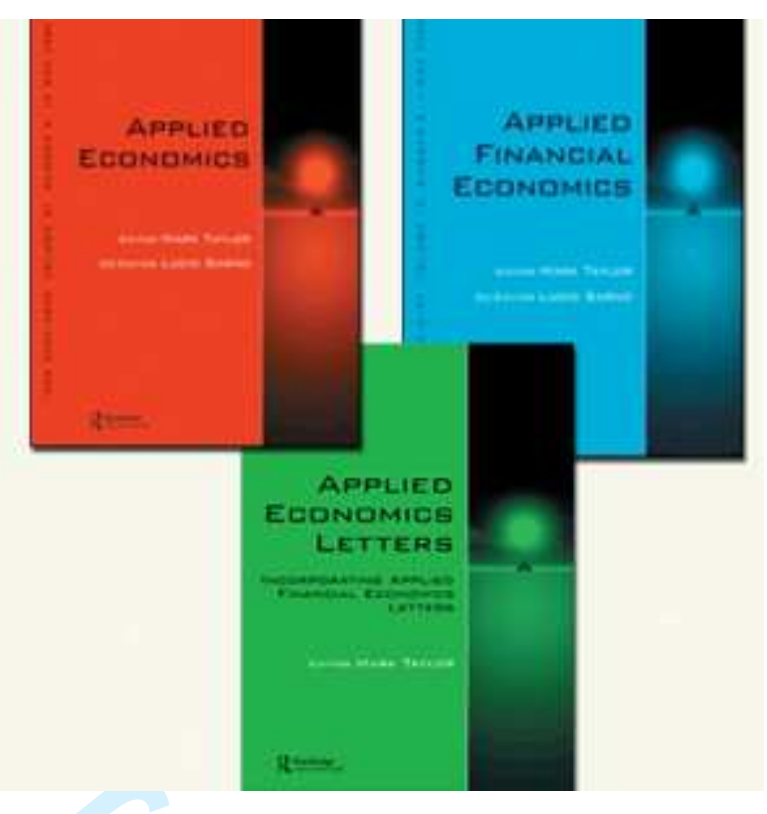

MONETARY POLICY RULES IN THEORY AND IN PRACTICE: EVIDENCE FROM THE UK AND THE US

\begin{tabular}{|c|c|}
\hline Journal: & Applied Economics \\
\hline Manuscript ID: & APE-07-0334.R1 \\
\hline Journal Selection: & Applied Economics \\
\hline $\begin{array}{r}\text { Date Submitted by the } \\
\text { Author: }\end{array}$ & 02-Aug-2007 \\
\hline Complete List of Authors: & Paez-Farrell, Juan; Cardiff University, Cardiff Business School \\
\hline JEL Code: & $\begin{array}{l}\text { E52 - Monetary Policy (Targets, Instruments, and Effects) < E5 - } \\
\text { Monetary Policy, Central Banking, and the Supply of Money and } \\
\text { Credit < E - Macroeconomics and Monetary Economics, E58 - } \\
\text { Central Banks and Their Policies < E5 - Monetary Policy, Central } \\
\text { Banking, and the Supply of Money and Credit < E - Macroeconomics } \\
\text { and Monetary Economics }\end{array}$ \\
\hline Keywords: & Monetary policy, interest rate rule \\
\hline
\end{tabular}

\section{SCHOLARONE ${ }^{m}$ \\ Manuscripts}




\title{
MONETARY POLICY RULES IN THEORY AND IN PRACTICE: EVIDENCE FROM THE UK AND THE US
}

\begin{abstract}
Given the large amount of interaction between research on monetary policy and its practice, this paper examines whether some simple monetary policy rules that have been proposed in the academic literature, part of which has originated from within central banks, provide a reasonable characterisation of actual policy in the UK and the US. The paper finds that the simple rule that describes best actual US monetary policy is a speed limit rule with dynamics, whilst for the UK it is a forward-looking rule. The simpler dynamics in the UK's monetary policy rule are reflective of the lower persistence of inflation as a result of its policy of inflation targeting.
\end{abstract}




\section{INTRODUCTION}

Monetary policy is increasingly represented in the form of a rule, whereby interest rates - the policy instrument - respond to economic variables with the aim of achieving a pre-specified policy objective.

The emphasis on rules harks back to the work of Friedman (1968) and Kydland and Prescott (1977). However, Friedman emphasised the importance of adherence to a rule in order to pre-empt attempts at stabilisation on the part of policymakers, given policymakers' ignorance about the correct model of the economy. ${ }^{1}$ In contrast, Kydland and Prescott's (1977) results stemmed from the monetary authority's desire to raise output beyond its potential level.

Interest in the use of monetary policy rules for stabilisation purposes gained prominence with New Keynesian models. ${ }^{2}$ Commitment to a monetary policy rule would be desirable provided the parameters in the policy rule remain within a reasonable range. Moreover, Taylor (1993) argued that US monetary policy could be usefully described not only by a mechanical rule but by a simple rule. In this case interest rates increased in response to rises in inflation above an implicit target and to a positive output gap.

\footnotetext{
${ }^{1}$ Given the assumption of the natural rate of unemployment (and interest) the real sector would inevitably always return to its natural rate, so that attempts at economic stabilisation could at most only help to bring this about at a faster rate.

${ }^{2}$ Also called New Neoclassical Synthesis models (Goodfriend and King, 1997)
} 
However, it is worth emphasising that one should interpret empirical results on Taylor-type rules as parsimonious representations of central bank behaviour. This does not necessarily imply that a mechanical rule is being followed, or indeed, that the Taylor rule is the only way of describing the data. ${ }^{3}$

Research on monetary policy rules - and Taylor-type rules in particular- has expanded on many fronts. From the empirical side, researchers have attempted to better characterise monetary policy by considering different additional variables or generalising the functional form.

From a theoretical perspective, most of the recent research has focused on the optimality of alternative monetary policy rules. This is generally done using stochastic dynamic general equilibrium (SDGE) models. Within this, some have posited ad hoc loss functions on the part of the central bank to derive the optimal monetary policy rule. ${ }^{4}$ A more theoretically satisfactory approach has relied on deriving the monetary policy rule that is obtained by maximising the welfare of the representative agent. The latter approach is obviously superior from a theoretical point of view, but may suffer from the fact that its conclusions could be specific to the model being studied and may not be robust to further modelling extensions.

Although the optimal rule could in principle be very complicated, this paper will focus on simple monetary policy rules, that is, where interest rates respond to a small

\footnotetext{
${ }^{3}$ On this, see Carare and Tchaidze (2005) and Minford et al. (2002).

${ }^{4}$ See for example, Kobayashi (2005).
} 
set of variables, with the Taylor rule being the most prominent example. Simple

rules have the advantage of being clearly understandable and transparent, so that the objectives of monetary policy be well understood. Moreover, uncertainty regarding the future path of nominal interest rates would be reduced given the predictability of the rule.

Whilst no central bank has publicly stated that it has followed an instrument rule, the Bank of England follows a targeting rule to implement its policy ${ }^{5}$ and the Fed's monetary policy objectives consist of achieving high employment, stable prices, economic growth and balance in the international accounts. ${ }^{6}$ This would seem to imply that estimating monetary policy rules for these two economies would be a pointless exercise, ${ }^{7}$ given that their central banks do not explicitly follow them. However, Taylor-type rules do have some influence on policy ${ }^{8}$ and it could be argued that central banks implicitly follow them. This would not be surprising given the two-way influence between monetary policy and recent theoretical developments ${ }^{9}$. An additional reason for investigating the relevance of a Taylor-type rule for the UK and the US also lies in the fact that, as mentioned above, an interest rate rule may provide a parsimonious description of actual policy even when it is not

\footnotetext{
${ }^{5}$ Nikolov (2002).

${ }^{6}$ This lack of specificity implies that it follows neither an instrument rule nor a target rule.

${ }^{7}$ Carare and Tchaidze (2005) discuss additional dangers in the use of Taylor rules, especially when used for policy recommendations.

${ }^{8}$ Nikolov (2002) states that Taylor rules are used at the Bank of England as an indicator of the stance of current policy; Yellen suggested that following a Taylor-type rule would represent good policy, which is remarkable when the alternative policy being considered was one of strict (over the medium term) inflation targeting, as argued by Broaddus (Federal Reserve Board 1995, p. 39-44).

${ }^{9}$ Indeed, given that much research on monetary policy is conducted within central banks, the fact that some of the proposed rules analysed in this paper were published near the end of the sample period does not preclude their relevance.
} 
adhered to by the monetary authorities. This is evidently relevant when one considers the large amount of research (especially for the US) that has found evidence of Taylor-type rules.

This paper aims to combine the two lines of research discussed above by considering to what extent some of the proposed rules emanating from theoretical models reflect actual central bank behaviour. To the extent that theoretical contributions have been able to model central bank objectives and constraints successfully, these will be shown in the paper.

\section{PROPOSED RULES FOR MONETARY POLICY}

The volume edited by Taylor (1999) provided one of the first thorough analyses on the macroeconomic consequences of alternative monetary policy rules in the presence of nominal rigidities. One of the benefits of the Taylor rule lies in the fact that under reasonable parameter values it will generally ensure a unique and determinate rational expectations equilibrium. ${ }^{10}$ Furthermore, from an empirical point of view its simplicity would help in being understood by the public. However, some authors have proposed similarly simple rules that nevertheless may possess superior features to the Taylor rule. In particular, the standard Taylor rule takes the form:

$$
R_{t}=\mu_{0}+\mu_{1} \pi_{t}+\mu_{2} x_{t}
$$

\footnotetext{
${ }^{10}$ See Woodford (2003, p. 252-261).
} 
where $\pi$ denotes the inflation rate value and $x$ denotes the output gap.

That is, the nominal interest rate is adjusted each quarter to respond to deviations in the target values of inflation and output. However, most empirical studies on Taylor rule variants have found that the lagged interest rate enters (1) and that it is strongly significant, modifying (1) to:

$R_{t}=\left(1-\mu_{3}\right)\left[\mu_{0}+\mu_{1} \pi_{t}+\mu_{2} x_{t}\right]+\mu_{3} R_{t-1}+v_{t}$

A theoretical rationale for the inclusion of the lagged interest rate in (2) can be found in Woodford (2003, p.280), in that the maintained high interest rates in response to rises in inflation or the output gap, for given $\mu_{1}, \mu_{2}$, have larger stabilising effects upon current output gap and inflation. A crucial feature that any monetary policy rule must possess is that it will ensure determinacy - both real and nominal - in the economy. The Taylor principle, $\mu_{1}>1$, is generally a necessary requirement for the uniqueness and stability of the equilibrium. $^{11}$

Nevertheless, as Carlstrom and Fuerst (2000, 2001) demonstrate, the timing on which the monetary policy rule is based can also be crucial in order to prevent disastrous effects on the real economy. To avoid this Carlstrom and Fuerst propose either current or backward-looking Taylor rules. However, this conclusion runs counter to the professed approach of explicit inflation targeting central banks, which

${ }^{11}$ The general condition can be found in Woodford (2003, p. 255). 
for the present paper is most relevant for the UK, as their approach is forwardlooking. Whereas backward-looking rules have been proposed on the grounds of avoiding indeterminacy, the rationale in support of forward-looking rules is based primarily on the fact that it takes into account the lags in the monetary transmission mechanism (Batini and Haldane, 1999).

These two different Taylor-type rules, which differ on the timing of the explanatory variables to which the monetary policy instrument reacts can be succinctly represented as:

$R_{t}=\left(1-\mu_{3}\right) E_{t-j}\left[\mu_{0}+\mu_{1} \pi_{t+k}+\mu_{2} x_{t+m}\right]+\mu_{3} R_{t-1}+v_{t}$

Where $j$ represents the possible information lag to which the central bank is subject. ${ }^{12} k(m)$ is a positive integer when the central bank reacts to expectations of future inflation (output gap), and a negative integer under a backward-looking Taylor-type rule.

In contrast to the proposed rules where the only difference concerns timing, Walsh (2003) has argued that a speed limit policy dominates inflation targeting as long as the model is predominantly forward-looking, since under a discretionary policy the central bank is able to achieve higher social welfare when it reacts to changes in the output gap. Whereas the Taylor rule can be derived from quadratic preferences, a

\footnotetext{
12 This would enable one to consider an operational monetary policy rule, as in McCallum and Nelson (1999).
} 
speed limit rule implicitly embodies a more general form. Consequently, the rule proposed by Walsh (2003) would take the form:

$$
R_{t}=\left(1-\mu_{3}\right)\left[\mu_{0}+\mu_{1} \pi_{t}+\mu_{2} \Delta x_{t}\right]+\mu_{3} R_{t-1}+v_{t}
$$

Lastly, another Taylor-type rule that has been prominent in the literature arises when one allows for a more flexible form of the central bank's objective function or if the economy's structure is non-linear. If the central bank's loss function is asymmetric, so that negative and positive deviations in the inflation rate and the output gap are assigned different weights, the optimal Taylor rule would be non-linear. ${ }^{13}$ Then the Taylor rule (2) would be modified to:

$$
R_{t}=\left(1-\mu_{3}\right) E_{t}\left[\mu_{0}+\mu_{1} \pi_{t}+\mu_{2} x_{t}+\mu_{4} \pi_{t}^{2}+\mu_{5} x_{t}^{2}+\mu_{6} \pi_{t} x_{t}\right]+\mu_{3} R_{t-1}+v_{t}
$$

Hence, the Taylor-type rules that this paper will focus on are forward and backwardlooking rules, speed limit and non-linear rules, as well as the basic Taylor rule (2) which will be considered as the benchmark.

\section{PREVIOUS ESTIMATES OF SIMPLE MONETARY POLICY RULES \\ Results from empirical studies that have estimated monetary policy rules have generally adopted one of two approaches. Most have been descriptive (Taylor, 1993) and have attempted to determine whether simple rules provide a useful description}

\footnotetext{
${ }^{13}$ An insightful analysis of such preferences in a monetary policy context can be found in Nobay and Peel (2003).
} 
of actual monetary policy behaviour. On the other hand, some authors have adopted a more normative approach, by characterising the monetary policy rules during periods of successful stabilisation and therefore attributing the superior outcome to the monetary policy rule of the central bank (Clarida et al., 2000).

Although the Fed does not have an explicit inflation target, it is committed to achieving low and stable prices as well as promoting employment growth. This implies that a monetary policy rule as a function of inflation and some measure of real activity may provide a realistic description of actual behaviour. In this sense Taylor's (1993) article, whilst using calibrated values in the policy rule, provided the first analysis of such a function. Furthermore, most estimated monetary policy rules for the Fed have found that a Taylor-type rule has provided a reasonable description of actual monetary policy. Clarida et. al. (2000) found that monetary policy during the Volcker-Greenspan years (1979:3 to 1996:4) was forward looking, in that the monetary policy instrument responded to forecasts of its target variables. More importantly, it satisfied the Taylor principle, ${ }^{14}$ with $\mu_{3}$, the coefficient on the lagged interest rate around 0.80 . Similar results are obtained by Nelson (2001) for the UK during the period 1992-97, whilst Adam et al. (2005) found that monetary policy was forward looking in terms of inflation, but responded to the current output gap.

The robustness of the Taylor principle has also been found in other studies. Ball and Tchaidze (2002) analysed US monetary policy in terms of inflation and

\footnotetext{
${ }^{14}$ The coefficient on the output gap (incorrectly defined as hp detrended output) was also high, at 0.93 .
} 
unemployment during the Greenspan years (1987-2000). They found that the rule had been relatively stable throughout the period once one allowed for changes in the NAIRU, with a coefficient on inflation of 1.29 for the "old economy" period (1987$1995)$ and 1.54 during the "new economy" years (1996-2000).

An additional issue concerns the inclusion of the lagged interest rate when estimating monetary policy rules. Although its inclusion is generally interpreted as reflecting partial adjustment in the behaviour of interest rates (Clarida et. al. 2000), Rudebusch (2002) has argued that the significant lagged interest rate is the result of serially correlated residuals. However, in attempting to disentangle the two effects, English et. al. (2003) found that the former argument is the dominant cause for the significance of the lagged interest rate.

Meanwhile, Surico (2003) found evidence in support of an asymmetric Taylor rule for the Fed for the period 1997-2002, whilst for the UK Martin and Milas’ (2004) results indicate that the Bank of England for the period 1992-2000 responded more to upward deviations of inflation away from the inflation target than when below the target, despite the official objective being symmetric.

More recently, Taylor and Davradakis (2006) using threshold models find that the Bank of England followed a forward looking Taylor rule when inflation was about half a percentage point above the inflation target. For inflation rates below this level the policy rule was best described as a random walk with a small positive coefficient on the output gap. 
Regarding evidence on the speed limit policy, Peel et al. (2004) did find empirical support for a speed limit policy for the US, although to this author's knowledge no research has been carried out regarding its relevance for the UK.

Nevertheless, despite the vast amount of research on estimating monetary policy rules for the US - and to a lesser extent, the UK - there is no clear consensus on the interest rate rule that best characterises each economy during a common sample period, such as the Greenspan era in the US and the period of inflation targeting in the UK.

\section{RESULTS FROM SOME PROPOSED SIMPLE INTEREST RATE RULES}

This section aims to compare the four monetary policy rules proposed by theoretical concerns using a common sample to determine if the behaviour of either the Fed or the Bank of England can be well characterised by one of these rules.

Rules where the interest rate responds directly to the exchange rate have not been included in this paper. Taylor (2001) is sceptical of including the exchange rate in the policy rule, as it is likely to worsen the outcome of stabilisation policies. Further support for this point of view emerges from Allsopp et al. (2006), who argue that under an inflation targeting regime with a flexible exchange rate, the latter matters only to the extent that it affects the inflation rate, rendering a direct reaction to it unnecessary. 
The results for the US are shown in Table 1 for the four rules considered in this paper. The data are quarterly and cover the period 1987:3 to 2004:4, which span most of the Greenspan years. ${ }^{15}$

Several measures of inflation were considered, including the GDP deflator, but the best fit was provided by the annual rate of change in personal consumption expenditures less food and energy, which is generally interpreted as a measure of core inflation in the US. The output gap is defined as current GDP as a proportion of the Congressional Budget Office-derived potential output, whilst the interest rate is measured as the average federal funds rate.

All rules are estimated by $\mathrm{GMM}^{16}$ using four lags of each explanatory variable as instruments, with the validity of the overidentifying restrictions confirmed the Jstatistic (p-values in parentheses). The null of residual normality (Jarque-Bera) is only rejected for the non-linear Taylor rule.

In estimating the forward-looking monetary policy rule, various timing horizons were considered, and only the one with the best fit is reported, which is the Taylortype rule where interest rates react to the forecast of inflation (the output gap) eight (four) quarters ahead.

[TABLE I]

\footnotetext{
${ }^{15}$ All data were taken from the Federal Reserve Bank of St. Louis.

${ }^{16}$ The backward-looking rule is estimated by least squares, with Newey-West standard errors in parentheses.
} 
The models yield similar coefficients for the autoregressive parameter, over 0.80 , which is consistent with the results obtained by Clarida et al. (2000). Whilst the Taylor principle is satisfied for all models - excluding the non-linear Taylor rule, which in any case performs poorly - although it ranges from 1.27 in the case of the pure Taylor rule (first column) to almost 3.9 under an inflation-forecast targeting rule. Similar results are obtained for the output gap, which is also significant in the first three models. Comparing the models on the basis of the Schwarz Bayesian information criterion (SBC) indicates that the standard Taylor rule provides the best description of the Fed's behaviour, which could lead one to conclude that despite the desirable features in the other monetary policy rules presented, these are not applicable to the US economy. ${ }^{17}$ However, despite the superior performance of the basic Taylor rule, the Q statistic is indicative of strong serial residual correlation, so that all of the equations may be mis-specified. This issue will be pursued further below.

For the UK, the sample in which the monetary policy rules were estimated is 1992:4 to $2004: 4$, which can be regarded as a single monetary policy regime, ${ }^{18}$ as the Bank of England had the official objective of an inflation target. The output gap is

\footnotetext{
${ }^{17}$ Obviously, more complicated rules are likely provide a more accurate description of actual interest rate behaviour, but this paper focuses on only a selection of simple rules with theoretical foundations. ${ }^{18}$ Adam et al. (2005) reported a change in regime pre- and post-independence of the Bank of England; however, Lord George, in an interview for the Financial Times on 2 May 2007, has stated that it was the introduction of inflation targeting and the general economic consensus in the UK that mattered most.
} 
measured as the Hodrick-Prescott filtered level of GDP ${ }^{19}$ (with a smoothing parameter of 1600), whilst the interest measure is the official Bank of England rate. Again, several inflation measures were considered, with the measure that yielded the best fit being the annual rate of RPI inflation. ${ }^{20}$ Interestingly, the regressions with RPIY inflation - which removes the effects of indirect taxes - yield poorer results, despite the fact that Cutler (2001) found that it was the best predictor of future inflation, in other words, it could be defined as core inflation.

Table 2 reports the estimates of the various models. It is interesting to note that the UK's monetary policy rule that best describes the data corresponds to the one that is closest to research emanating from the Bank of England (Batini and Haldane, 1999 and Nikolov, 2002), that is, a forward looking rule. For the sample considered the best fit is obtained when the forecast horizon is four quarters for both inflation and the output gap. As with the Fed, the Taylor principle is satisfied, ${ }^{21}$ although the coefficient on the output gap is higher than that on inflation, albeit less precisely estimated. Moreover, whilst for the US the results on inflation were generally consistent across models, at least with regards to the coefficient on inflation, for the UK results are highly sensitive to the timing of the Taylor rule. This is especially the case with the backward-looking Taylor rule, indicating that the results are highly sensitive to the specified horizon.

\footnotetext{
${ }^{19}$ Although this is common practice, as mentioned earlier one should be aware that this is not the equivalent measure from a theoretical output gap measure.

${ }^{20}$ In the estimations, inflation is then RPI minus the official inflation target. Modifying this to the gap using first RPIX and then CPI inflation, the Bank's official target, has not effect on the results.

${ }^{21}$ However, it is not significantly above unity.
} 
[TABLE 2]

Although the results from Table 2 are consistent with the accepted wisdom regarding the behaviour of the Bank of England, the Q-statistic again indicates substantial residual autocorrelation. Given that this paper has argued that the monetary policy rules being estimated are only rough approximations to actual central bank behaviour, as no central bank explicitly (and from the results, implicitly) follows a mechanical interest rate rule, monetary policy may also be responding to other events. However, a potential reason for the high Q statistic concerns the behaviour of interest rates and the modelling framework.

Therefore, it could be argued that the dynamics of interest rates are not captured by the models presented above, but that an error correction form provides a superior representation of the data ${ }^{22}$. Early empirical support for this formulation can be found in Judd and Rudebusch (1998), in the form of a modified basic Taylor rule: ${ }^{23}$

$$
\Delta R_{t}=\mu_{0}+\mu_{1} \pi_{t-1}+\mu_{2} x_{t-1}+\mu_{3} R_{t-1}+\mu_{4} \Delta R_{t-1}+v_{t}
$$

To determine whether the residual autocorrelation is due to the fact of the poorer dynamics in the previous models, they are now presented in Table 3 for the speed-

\footnotetext{
${ }^{22}$ In effect, equation (6) can be seen as a re-parameterisation of an autoregressive distributed lag (ARDL) model embodying an error correction model. Hence it can be interpreted as a Taylor rule but with richer dynamics.

${ }^{23}$ Their estimation was conducted by least squares on the grounds that given the lags in the monetary transmission mechanism, reverse causation from interest rates to inflation and output was unlikely.
} 
limit and non-linear Taylor rules. In addition, difference rules have also been found to be optimal under a variety of contexts, with the underlying rationale being an extension to the inclusion of the lagged interest rate in the Taylor rule. ${ }^{24}$ The rationale is that the commitment to maintaining higher interest rates in the future in response to a positive inflationary or output gap shock in the present induces greater stabilisation in these two variables.

In addition, Orphanides and Williams (2002) propose a difference rule on the grounds that it is more robust in the face of problems measuring the natural rate. The rule they put forward takes them form:

$$
\Delta R_{t}=\mu_{0}+\mu_{1} \pi_{t}+\mu_{2} \Delta u e_{t}
$$

where $u e$ denotes the unemployment rate. ${ }^{25}$ Giannoni and Woodford (2003) proposed an alternative rule, which can be interpreted as a speed limit rule that is optimal from a timeless perspective within the context of the model they analyse, and is represented by equation (8):

$$
\Delta R_{t}=\mu_{0}+\mu_{1} \pi_{t}+\mu_{2} \Delta x_{t}+\mu_{3} R_{t-1}+\mu_{4} \Delta R_{t-1}
$$

\footnotetext{
${ }^{24}$ An important methodological issue concerns the stationarity properties of the interest rate. For the US, both the ADF and Phillips-Perron test reject stationarity at the $1 \%$ level, but not at the $5 \%$ level. For the UK, although the ADF test rejects stationarity at the $1 \%$ level, the Phillips-Perron gives the same results as for the US. Hence the results are not conclusive, but are indicative of substantial persistence in the series. Moreover, there are strong theoretical reasons to believe that the interest rate is a stationary series, especially in the case of an inflation targeting regime.

${ }^{25}$ This is measured as the civilian unemployment rate in the present paper.
} 
Lastly, Walsh (2005) argued that a difference rule provide a robust simple rule when faced with possible parameter misspecification, especially regarding the degree of inflation inertia. ${ }^{26}$ This leads to the simple interest rule:

$$
\Delta R_{t}=\mu_{0}+\mu_{1} \pi_{t}+\mu_{2} \Delta x_{t}
$$

Table 3 presents the monetary policy rules in differences for the US. Of the different measures of inflation considered, the best fit was provided by the quarterly percentage change in the GDP deflator (at an annualised rate). Although the dynamic Taylor rule provides a reasonable description of movements in the Federal funds rate, the best model is given by the speed limit policy, as initially put forward by Walsh (2003), but with allowance for richer dynamics. ${ }^{27}$ Moreover, the long-run response to the inflation rate of 2 is consistent with previous findings in the literature, whilst there is also a strong response to changes in the output gap, of 0.29 .

The monetary policy rules considered by Walsh (2005), and Giannoni and Woodford (2003) also include a speed-limit component, which is even stronger, although less precisely estimated. In both cases the coefficient on inflation is strongly significant. Nevertheless, the Giannoni-Woodford rationale for the particular rule they derive does not provide an appropriate characterisation of interest rate behaviour, as the coefficient on the lagged interest rate should be positive.

\footnotetext{
${ }^{26}$ However, as Walsh also points out, this rule performs substantially worse than the optimal rule under more general misspecification.

${ }^{27}$ Previous empirical support for a speed limit rule was found by Peel et al. (2004).
} 
Lastly, while in the non-linear specification the inflation rate provides little explanatory power, the Orphanides-Williams formulation yields a negative coefficient on the inflation rate. Their generally poor empirical performance is reflected in the high SBC values they yield.

Overall, in analysing the Fed's behaviour within the scope of simple interest rate rules, an error correction formulation in which interest rates follow a speed limit policy does seem to provide a reasonable characterisation of the data and this formulation has a theoretical basis to support it.

[TABLE 3]

The same models estimated for the UK are presented in Table 4, but none of the models can describe the data well. The Orphanides-Williams, and the GiannoniWoodford specifications suffer from the same problems as in the US estimation. The coefficient on inflation is strongly significant under the specification considered by Walsh (2005), although the change in the output gap is insignificant at the $10 \%$ level, whilst residual normality is also rejected.

[TABLE 4] 
Once again, the non-linear formulation is unsuccessful at characterising the data, with the coefficients on inflation being insignificant. ${ }^{28}$ However, in contrast to the US results, the interaction coefficient between output and inflation is positive and significant, as expected.

Overall, within the model in differences, UK monetary policy is best described by a simple Taylor rule, although this is nevertheless a poor representation. There are two reasons why this result arises. First, UK monetary policy does seem to be more forward looking than in the US, so that rule (3) provides a better characterisation of interest rates. Secondly, and most importantly, there is evidence that inflation is a less persistent series under an inflation targeting regime; ${ }^{29}$ this can account for the support of the ARDL model for the US but its rejection in the case of the UK.

\section{CONCLUSION}

In recent decades there has been a large amount of interaction between central bank and academic researchers on monetary policy issues, as pointed out by McCallum (1999). Among the most prominent topics have been not only the objectives of monetary policy, but also the variables that the monetary policy instrument, typically a short term interest rate, reacts to.

It is generally agreed that a necessary criterion for any policy rule is that it should ensure determinacy and that this result be robust under a variety of models. Nevertheless, within rules that do yield a unique rational expectations equilibrium,

\footnotetext{
${ }^{28}$ A potential explanation is that the nonlinearity that best describes the data may be the one used by Taylor and Davradakis (2006) - a threshold model - and not equation (5).

${ }^{29}$ See Benati (2007).
} 
different rules may possess additional benefits, such as being robust to parameter uncertainty, being more efficient (in the sense of Ball, 1999), or better capturing the preferences of policymakers.

\begin{abstract}
Although no central bank has indicated that it follows a mechanical policy instrument rule, economic research normally assumes or derives particular rules with the aim of analysing their consequences under different modelling formulations. Given that much of this research has been conducted within central banks, one could argue that some of the proposed monetary policy rules have emerged as a result of carrying out monetary policy, whilst at the same time policymakers are influenced by academic developments. In essence, although central banks may not adhere to a rule, given the interactions mentioned above it could be argued that a rule may provide a close description of actual monetary policy.
\end{abstract}

Constraining the analysis to simple interest rate rules, this paper has considered whether some prominent simple monetary policy rules that have been proposed in the academic literature have been reflected in practice at either the Federal Reserve or the Bank of England.

The introduction of inflation targeting seems to have led to a substantial decrease in inflation persistence, and this has been reflected in the rule that best characterises interest rate behaviour in the UK, that of a forward looking Taylor rule. Given that the US does not have explicit numerical objectives - as well as having real objectives - the simple monetary policy rule that provides a reasonable 
description of interest rate behaviour is a speed limit rule. This follows Walsh (2003), except for the fact that it embodies richer dynamics in the form of an error correction model, or alternatively, in an ARDL representation.

Thus both central banks' estimated interest rate rules do have underlying theoretical support, and the particular rules that provide the best description of monetary policy in each country are consistent with their official policy objectives.

Lastly, while a considerable amount of research has been devoted to estimating monetary policy rules under varying assumptions, there has been little effort to assess which of these rules provides the best description of actual behaviour using the same sample period. In focusing on a selection of simple rules, the results of this paper can be regarded as a first step in that endeavour.

\section{ACKNOWLEDGEMENTS}

I would like to thank an anonymous referee for helpful comments.

\section{REFERENCES}

Adam, C. Cobham, D. and Girardin E. (2005) Monetary frameworks and institutional constraints: UK monetary policy reaction functions, 1985-2003, Oxford Bulletin of Economic and Statistics 67, 497-516.

Allsopp, C., Kara, A. and Nelson, E. (2006) United Kingdom inflation targeting and the exchange rate, The Economic Journal, 116(June), F232-F244. 
Ball, L. (1999) Policy rules for open economies, in Monetary Policy Rules (Ed.) J. B. Taylor, University of Chicago Press, Chicago.

Ball, L. and Tchaidze, R. (2002) The Fed and the new economy, American Economic Review, AEA 2002 Papers and Proceedings, 92(2) p. 108-114.

Batini, N. and Haldane A. G. (1999) Forward-looking rules for monetary policy, in Monetary Policy Rules (Ed.) J. B. Taylor, University of Chicago Press, Chicago.

Benati, L. (2007) Investigating inflation persistence across monetary regimes, mimeo.

Carare, A. and Tchaidze R. (2005) The use and abuse of Taylor rules: how precisely can we estimate them? IMF Working Paper WP/05/148.

Carlstrom C. T. and Fuerst, T. S. (2000) Forward-looking versus backward-looking Taylor rules, Federal Reserve Bank of Cleveland Working Paper No. 00-09.

Carlstrom C. T. and Fuerst, T. S. (2001) Timing and real indeterminacy in monetary models. Journal of Monetary Economics, 47, p. 285-298.

Clarida, R., Galí, J. and Gertler, M. (2000) Monetary policy rules and macroeconomic stability: evidence and some theory, Quarterly Journal of Economics, 115(1), 147180.

Cutler, J. (2001) Core inflation in the UK, External MPC Discussion Paper No. 3, Bank of England.

English, W. B., Nelson, W. R. and Sack, B. P. (2003). Interpreting the significance of the lagged interest rate in estimated monetary policy rules, Contributions to Macroeconomics, 3(1), Article 5.

Federal Reserve Board. (1995) Federal Open Market Committee Transcripts, FOMC Meeting 31 January - 1 February, www.federalreserve.gov/fomc/transcripts.

Friedman, M. (1968) The role of monetary policy, American Economic Review, 58, 1-17.

Giannoni, M. P. and Woodford M. (2003) How forward-looking is optimal monetary policy? Journal of Money, Credit and Banking, 35(6), 1425-1469. 
Goodfriend, M. and King, R. G. (1997) The New Neoclassical Synthesis and the role of monetary policy, NBER Macroeconomics Annual, 231-83.

Judd, J. P., and Rudebusch, G. D. (1998) Taylor's rule and the Fed: 1970-97, Federal Reserve Bank of San Francisco Economic Review, No. 3, 3-16.

Kydland, F. E. and Prescott, E. C. (1977) Rules rather than discretion: the inconsistency of optimal plans, Journal of Political Economy, 85(3), 473-91.

Kobayashi, T. (2005) Optimal monetary policy and the role of hybrid inflationprice-level targets, Applied Economics 37, 2119-2125.

McCallum, B. T. (1999) Recent developments in monetary policy analysis: the roles of theory and evidence, Journal of Economic Methodology, 6(2), 171-98.

McCallum, B. T. and Nelson, E. (1999) Performance of operational monetary policy rules in an estimated semi-Classical structural model, in Monetary Policy Rules (Ed.) J. B. Taylor, University of Chicago Press, Chicago.

Martin, C. and Milas, C. (2004) Modelling monetary policy: inflation targeting in practice, Economica 71(282), 209-221.

Minford, P., Perugini, F. and N. Srinivasan. (2002) Are interest rate regressions evidence for a Taylor rule? Economics Letters, 76(1), 145-150.

Nelson, E. (2001) UK monetary policy 1972-1997: a guide using Taylor rules, CEPR discussion paper 2931.

Nikolov, K. (2002) Monetary policy at the Bank of England, mimeo, available from http://www.ecb.int/events/conferences/html/policy_rules.en.html.

Nobay, A. R. and Peel, D. A. (2003) Optimal discretionary monetary policy in a model of asymmetric central bank preferences, Economic Journal, 113, 657-65.

Orphanides, A. and Williams, J. (2002) Robust monetary policy rules with unknown natural rates. Brookings Papers on Economic Activity, 2, 63-118. 
Peel, D. A., Paya, I. and Venetis, I. (2004) Estimates of US monetary policy rules with allowance for changes in the output gap, Applied Economics Letters, 11, 601-605.

Rudebusch, G. (2002) Term structure evidence on interest rate smoothing and monetary policy inertia, Journal of Monetary Economics 49(6), 1161-1187.

Surico, P. (2003) Asymmetric reaction functions for the Euro area, Oxford Review of Economic Policy, 19(1), 44-57.

Taylor, J. B. (1993) Discretion versus rules in practice, Carnegie Rochester Series on Public Policy 39, 195-214.

Taylor, J. B. (Ed.) (1999) Monetary Policy Rules, NBER Business Cycle Series, 2, The University of Chicago Press, Chicago.

Taylor, J. B. (2001) The role of the exchange rate in monetary policy rules, American Economic Review, 91(2), 263-267.

Taylor, M. P. and Davradakis, E. (2006) Interest rate setting and inflation targeting: evidence of a nonlinear Taylor rule for the United Kingdom, Studies in Nonlinear Dynamics \& Econometrics, 10(4), Article 1.

Walsh, C. (2003) Speed limit policies: the output gap and optimal monetary policy, American Economic Review, 93(1), 265-278.

Walsh, C. (2005) Parameter misspecification and robust monetary policy rules. ECB Working Paper, No. 477.

Woodford, M. (2003) Interest and Prices: Foundations of a Theory of Monetary Policy, Princeton University Press, New Jersey. 
Table 1. Estimated simple interest rate rules for the US (1987:3-2004:4)

\begin{tabular}{|c|c|c|c|c|c|}
\hline & Taylor Rule & $\begin{array}{l}\text { Backward Taylor } \\
\text { Rule }\end{array}$ & $\begin{array}{l}\text { Forward } \\
\text { Taylor Rule }\end{array}$ & $\begin{array}{l}\text { Non-linear } \\
\text { Taylor Rule }\end{array}$ & $\begin{array}{l}\text { Speed } \\
\text { limit }\end{array}$ \\
\hline$\mu_{0}$ & $\begin{array}{c}1.80 \\
(0.75)\end{array}$ & $\begin{array}{c}1.32 \\
(1.07)\end{array}$ & $\begin{array}{l}-4.19 \\
(1.52)\end{array}$ & $\begin{array}{c}-38.97 \\
(125)\end{array}$ & $\begin{array}{c}-4.84 \\
(2.38)\end{array}$ \\
\hline$R_{t-1}$ & $\begin{array}{c}0.86 \\
(0.03)\end{array}$ & $\begin{array}{c}0.82 \\
(0.06)\end{array}$ & $\begin{array}{c}0.88 \\
(0.03)\end{array}$ & $\begin{array}{c}0.96 \\
(0.07)\end{array}$ & $\begin{array}{c}0.92 \\
(0.03)\end{array}$ \\
\hline$\pi_{t}$ & $\begin{array}{c}1.27 \\
(0.35)\end{array}$ & & & $\begin{array}{l}36.0 \\
(104)\end{array}$ & $\begin{array}{c}3.82 \\
(0.78)\end{array}$ \\
\hline$\pi_{t+k}$ & & $\begin{array}{c}1.52 \\
(0.40)\end{array}$ & $\begin{array}{c}3.89 \\
(0.61)\end{array}$ & & \\
\hline$x_{t}$ & $\begin{array}{l}1.36 \\
(0.17)\end{array}$ & & & $\begin{array}{l}-9.87 \\
(17.9)\end{array}$ & \\
\hline$x_{t+k}$ & & $\begin{array}{c}1.28 \\
(0.20)\end{array}$ & $\begin{array}{c}2.09 \\
(0.46)\end{array}$ & & \\
\hline$\pi_{t}^{2}$ & & & & $\begin{array}{l}-5.68 \\
(17.4)\end{array}$ & \\
\hline$x_{t}^{2}$ & & & & $\begin{array}{c}0.58 \\
(1.70)\end{array}$ & \\
\hline$\pi_{t} x_{t}$ & & & & $\begin{array}{c}6.93 \\
(12.1)\end{array}$ & \\
\hline$\Delta x_{t}$ & & & & & $\begin{array}{l}11.57 \\
(5.0)\end{array}$ \\
\hline $\mathbf{J B}$ & 6.4 & 4.48 & 1.63 & 13.0 & 0.15 \\
\hline $\begin{array}{l}\text { B-P- } \\
\text { L }\end{array}$ & 15.0 & 59.1 & 50.1 & 51.6 & 18.5 \\
\hline SBC & -1.62 & -1.50 & -1.24 & -0.91 & -0.79 \\
\hline $\mathbf{J}$ & $\begin{array}{c}8.7 \\
(0.36)\end{array}$ & & $\begin{array}{c}5.7 \\
(0.68)\end{array}$ & $\begin{array}{l}5.15 \\
(0.53)\end{array}$ & $\begin{array}{c}6.92 \\
(0.55)\end{array}$ \\
\hline
\end{tabular}

Notes: B-P-L denotes the Box-Pierce-Ljung Q statistic for residual autocorrelation to the 4th order, which is distributed as chi-squared (4) with critical value of 9.49 SBC is the Schwarz Bayesian Criterion and $\mathrm{J}$ is a test of overidentifying restrictions. $k$ is -1 for the backwardlooking model and 8 (4) for inflation (output gap) when forward looking. The backwardlooking rule is estimated by least squares (Newey-West standard errors in parentheses); all other rules are estimated by GMM with the Newey-West criterion being used to choose the lag truncation parameter. The different models are described in the text. 
Table 2. Estimated simple interest rate rules for the UK (1992:4-2004:4)

\begin{tabular}{|c|c|c|c|c|c|}
\hline & $\begin{array}{l}\text { Taylor } \\
\text { Rule }\end{array}$ & $\begin{array}{c}\text { Forward } \\
\text { Taylor Rule }\end{array}$ & $\begin{array}{l}\text { Backward Taylor } \\
\text { Rule }\end{array}$ & $\begin{array}{l}\text { Non-linear } \\
\text { Taylor Rule }\end{array}$ & $\begin{array}{l}\text { Speed } \\
\text { Limit }\end{array}$ \\
\hline$\mu_{0}$ & $\begin{array}{c}5.16 \\
(0.37)\end{array}$ & $\begin{array}{c}5.01 \\
(0.26)\end{array}$ & $\begin{array}{c}5.19 \\
(0.51)\end{array}$ & $\begin{array}{c}14.88 \\
(58.99)\end{array}$ & $\begin{array}{c}4.58 \\
(0.37)\end{array}$ \\
\hline$R_{t-1}$ & $\begin{array}{c}0.86 \\
(0.04)\end{array}$ & $\begin{array}{c}0.79 \\
(0.04)\end{array}$ & $\begin{array}{c}0.85 \\
(0.06)\end{array}$ & $\begin{array}{c}0.99 \\
(0.04)\end{array}$ & $\begin{array}{c}0.76 \\
(0.07)\end{array}$ \\
\hline$\pi_{t}$ & $\begin{array}{l}-0.43 \\
(0.50)\end{array}$ & & & $\begin{array}{c}7.38 \\
(34.9)\end{array}$ & $\begin{array}{c}0.71 \\
(0.40)\end{array}$ \\
\hline$\pi_{t+k}$ & & $\begin{array}{c}1.10 \\
(0.29)\end{array}$ & $\begin{array}{l}-0.17 \\
(0.67)\end{array}$ & & \\
\hline$x_{t}$ & $\begin{array}{c}3.93 \\
(1.17)\end{array}$ & & & $\begin{array}{c}33.45 \\
(152.1)\end{array}$ & \\
\hline$x_{t+k}$ & & $\begin{array}{c}1.67 \\
(0.72)\end{array}$ & $\begin{array}{c}2.10 \\
(1.06)\end{array}$ & & \\
\hline$\pi_{t}^{2}$ & & & & $\begin{array}{l}-26.1 \\
(135)\end{array}$ & \\
\hline$x_{t}^{2}$ & & & & $\begin{array}{c}-25.9 \\
(133.6)\end{array}$ & \\
\hline$\pi_{t} x_{t}$ & & & & $\begin{array}{l}81.5 \\
(391)\end{array}$ & \\
\hline$\Delta x_{t}$ & & & & & $\begin{array}{c}0.70 \\
(1.70)\end{array}$ \\
\hline $\mathbf{J B}$ & 1.12 & 4.76 & 1.1 & 1.1 & 2.64 \\
\hline B-P-L & 24.0 & 19.9 & 21.5 & 18.59 & 23.2 \\
\hline SBC & -1.59 & -1.96 & -1.62 & -1.31 & -1.40 \\
\hline $\mathbf{J}$ & $\begin{array}{c}6.5 \\
(0.99)\end{array}$ & $\begin{array}{c}6.12 \\
(0.99)\end{array}$ & & $\begin{array}{c}4.27 \\
(0.99)\end{array}$ & $\begin{array}{c}5.68 \\
(0.99)\end{array}$ \\
\hline
\end{tabular}

Notes: As in Table 1, except that in the forward-looking model the forecast horizon for both inflation and the output gap are four quarters. 
Table 3. Estimated simple differenced interest rate rules for the US (1987:3-2004:4)

\begin{tabular}{|c|c|c|c|c|c|c|}
\hline & $\begin{array}{l}\text { Taylor } \\
\text { Rule }\end{array}$ & Speed Limit & Nonlinear & $\begin{array}{l}\text { Orphanides- } \\
\text { Williams }\end{array}$ & $\begin{array}{l}\text { Walsh } \\
(2005)\end{array}$ & $\begin{array}{l}\text { Giannoni } \\
\text { Woodford }\end{array}$ \\
\hline$\mu_{0}$ & $\begin{array}{c}0.17 \\
(0.10)\end{array}$ & $\begin{array}{l}-0.04 \\
(0.10)\end{array}$ & $\begin{array}{c}0.21 \\
(0.24)\end{array}$ & $\begin{array}{c}0.03 \\
(0.13)\end{array}$ & $\begin{array}{l}-0.58 \\
(0.19)\end{array}$ & $\begin{array}{l}-0.28 \\
(0.16)\end{array}$ \\
\hline$\pi_{t}$ & & & & $\begin{array}{l}-0.10 \\
(0.05)\end{array}$ & $\begin{array}{c}0.28 \\
(0.07)\end{array}$ & $\begin{array}{c}0.17 \\
(0.05)\end{array}$ \\
\hline$\Delta x_{t}$ & & & & & $\begin{array}{c}0.55 \\
(0.18)\end{array}$ & $\begin{array}{c}0.68 \\
(0.15)\end{array}$ \\
\hline$\pi_{t-1}$ & $\begin{array}{c}0.10 \\
(0.04)\end{array}$ & $\begin{array}{c}0.10 \\
(0.04)\end{array}$ & $\begin{array}{c}0.11 \\
(0.20)\end{array}$ & & & \\
\hline$x_{t-1}$ & $\begin{array}{c}0.07 \\
(0.03)\end{array}$ & & $\begin{array}{c}0.11 \\
(0.05)\end{array}$ & & & \\
\hline$R_{t-1}$ & $\begin{array}{l}-0.08 \\
(0.02)\end{array}$ & $\begin{array}{l}-0.05 \\
(0.02)\end{array}$ & $\begin{array}{l}-0.09 \\
(0.02)\end{array}$ & & & $\begin{array}{r}-0.022 \\
(0.03)\end{array}$ \\
\hline$\Delta R_{t-1}$ & $\begin{array}{c}0.67 \\
(0.11)\end{array}$ & $\begin{array}{c}0.60 \\
(0.07)\end{array}$ & $\begin{array}{c}0.67 \\
(0.12)\end{array}$ & & & $\begin{array}{c}0.48 \\
(0.10)\end{array}$ \\
\hline$\Delta x_{t-1}$ & & $\begin{array}{c}0.29 \\
(0.09)\end{array}$ & & & & \\
\hline$\pi_{t-1}^{2}$ & & & $\begin{array}{l}-0.002 \\
(0.04)\end{array}$ & & & \\
\hline$x_{t-1}^{2}$ & & & $\begin{array}{l}-0.01 \\
(0.01)\end{array}$ & & & \\
\hline$\Delta x_{t-1}^{2}$ & & & & & & \\
\hline$\pi_{t-1} x_{t-1}$ & & & $\begin{array}{l}-0.02 \\
(0.02)\end{array}$ & & & \\
\hline$\Delta u e_{t}$ & & & & $\begin{array}{l}-1.95 \\
(0.18)\end{array}$ & & \\
\hline $\mathbf{J B}$ & 3.95 & 0.70 & 5.03 & 3.03 & 2.90 & 3.17 \\
\hline B-P-L & 0.27 & 0.16 & 0.26 & 10.5 & 15.6 & 0.72 \\
\hline $\begin{array}{l}\text { SBC } \\
\mathbf{J}\end{array}$ & -1.95 & -2.07 & -1.78 & $\begin{array}{c}-1.59 \\
6.76\end{array}$ & $\begin{array}{c}-1.12 \\
8.67\end{array}$ & $\begin{array}{c}-1.45 \\
7.17\end{array}$ \\
\hline
\end{tabular}

Notes: As in Table 1. 
Table 4. Estimated simple differenced interest rate rules for the UK (1992:4-2004:4)

\begin{tabular}{|c|c|c|c|c|c|c|}
\hline & $\begin{array}{l}\text { Taylor } \\
\text { Rule }\end{array}$ & Speed Limit & Nonlinear & $\begin{array}{l}\text { Orphanides- } \\
\text { Williams }\end{array}$ & $\begin{array}{l}\text { Walsh } \\
(2005)\end{array}$ & $\begin{array}{l}\text { Giannoni } \\
\text { Woodford }\end{array}$ \\
\hline$\mu_{0}$ & $\begin{array}{c}0.74 \\
(0.32)\end{array}$ & $\begin{array}{c}0.85 \\
(0.49)\end{array}$ & $\begin{array}{c}0.58 \\
(0.25)\end{array}$ & $\begin{array}{l}-0.54 \\
(0.08)\end{array}$ & $\begin{array}{l}-0.08 \\
(0.05)\end{array}$ & $\begin{array}{c}0.58 \\
(0.41)\end{array}$ \\
\hline$\pi_{t}$ & & & & $\begin{array}{l}-0.15 \\
(0.08)\end{array}$ & $\begin{array}{c}0.15 \\
(0.03)\end{array}$ & $\begin{array}{l}-0.02 \\
(0.07)\end{array}$ \\
\hline$\Delta x_{t}$ & & & & & $\begin{array}{c}0.59 \\
(0.37)\end{array}$ & $\begin{array}{c}0.65 \\
(0.35)\end{array}$ \\
\hline$\pi_{t-1}$ & $\begin{array}{l}-0.08 \\
(0.06)\end{array}$ & $\begin{array}{l}-0.04 \\
(0.06)\end{array}$ & $\begin{array}{l}-0.03 \\
(0.09)\end{array}$ & & & \\
\hline$x_{t-1}$ & $\begin{array}{c}0.16 \\
(0.12)\end{array}$ & & $\begin{array}{c}0.14 \\
(0.16)\end{array}$ & & & \\
\hline$R_{t-1}$ & $\begin{array}{l}-0.14 \\
(0.06)\end{array}$ & $\begin{array}{l}-0.16 \\
(0.09)\end{array}$ & $\begin{array}{l}-0.11 \\
(0.06)\end{array}$ & & & $\begin{array}{l}-0.12 \\
(0.08)\end{array}$ \\
\hline$\Delta R_{t-1}$ & $\begin{array}{c}0.44 \\
(0.18)\end{array}$ & $\begin{array}{c}0.56 \\
(0.12)\end{array}$ & $\begin{array}{c}0.38 \\
(0.21)\end{array}$ & & & $\begin{array}{c}0.53 \\
(0.12)\end{array}$ \\
\hline$\Delta x_{t-1}$ & & $\begin{array}{c}0.15 \\
(0.11)\end{array}$ & & & & \\
\hline$\pi_{t-1}^{2}$ & & & $\begin{array}{l}-0.02 \\
(0.11)\end{array}$ & & & \\
\hline$x_{t-1}^{2}$ & & & $\begin{array}{l}-0.03 \\
(0.10)\end{array}$ & & & \\
\hline$\Delta x_{t-1}^{2}$ & & & & & & \\
\hline$\pi_{t-1} x_{t-1}$ & & & $\begin{array}{c}0.22 \\
(0.10)\end{array}$ & & & \\
\hline$\Delta u e_{t}$ & & & & & & \\
\hline JB & & & & $\begin{array}{l}-3.88 \\
(0.59)\end{array}$ & & \\
\hline B-P-L & 7.4 & 31.1 & 0.48 & 0.16 & 155.3 & 57.5 \\
\hline SBC & 6.0 & 3.40 & 6.9 & 3.22 & 11.3 & 2.02 \\
\hline $\mathbf{J}$ & -1.80 & -1.73 & -1.73 & $\begin{array}{c}-0.99 \\
4.50\end{array}$ & $\begin{array}{c}-1.15 \\
7.3\end{array}$ & $\begin{array}{c}-1.51 \\
5.29\end{array}$ \\
\hline
\end{tabular}

Notes: As in Table 1. 